Anselmi, N., Saraceni, A., Anselmi, A. (2021): Incidence of Armillaria species in agrarian, forest and ornamental ecosystems of the Lazio region. Agriculture and Forestry, 67 (1): 7-25.

DOI: 10.17707/AgricultForest.67.1.01

Naldo ANSELMI,

Alessandro SARACENI ${ }^{1}$, Andrea ANSELMI ${ }^{2}$

\title{
INCIDENCE OF ARMILLARIA SPECIES IN AGRARIAN, FOREST AND ORNAMENTAL ECOSYSTEMS OF THE LAZIO REGION.
}

\begin{abstract}
SUMMARY
A series of investigations to detect the incidence of the various species of Armillaria in the different ecosystems of the Lazio region of Italy have been carried out in the last fifteen years.

A. ostoyae has been found only in forests of Abies alba and Pinus spp, over 700 meters a.s.1.; A. gallica and A. tabescens, with a predominantly saprophytic character, have been found on very declining oak forests. The most numerous attacks have been ascribed to $A$. mellea, in various orchards, vineyards, olive groves, forests, wood plantations, shade trees and other ornamental ecosystems, on broadleaved trees and shrubs, but also on coniferous ones, often as a weakness parasite, but also with evident pathogenic capacity, especially in case of high inoculum pressure. The different predisposing factors have been discussed, with particular emphasis on the declining of the plants due to climatic change. The work concludes with some hints on the possible control strategies.
\end{abstract}

Keywords: Armillaria, orchards, forests, wood plantations, ornamental trees, predisposing factors, control.

\section{INTRODUCTION}

Armillaria is a fungal genus of the class Basidiomycetes, order Agaricales, necrotrophic, with rhizomorphs and, except for A. tabescens, with basidiomes equipped with rings (Figures 1-2). Its roles include primary pathogen, stressinduced secondary invader, and saprophyte. As pathogen, Armillaria invades the bark and cambium region of the root, collar, and basal part of the trunk, killing roots and trees of all sizes. Sign of its presence on the affected subject is the appearance, under the bark, of cream-white mycelium plaques with a characteristic fan shape, which can go up along the stem even for one or two

\footnotetext{
${ }^{1}$ Naldo Anselmi (corresponding author: anselmicasa@live.it), Alessandro Saraceni, Department of Innovation in Biological, Agro-food and Forest systems (DIBAF), University of Tuscia, Via S. Camillo De Lelli, snc., 01100 Viterbo. ITALIA

2 Andrea Anselmi, Università Cattolica del Sacro Cuore di Piacenza, ITALIA

Notes: The authors declare that they have no conflicts of interest. Authorship Form signed online. 
meters (Figure 3), and the possible production, in the autumn months, of basidiomes in groups (Figures 1-2). Symptoms above ground are yellowish or undersized foliage, premature leaf drop, branch dieback in the upper crown, or rapid browning and death of the entire plant (see below), that can collapse to the ground for uprooting. As a root disease fungus, it is one of the most prominent killers and decayers of deciduous and coniferous trees and shrubs in orchards, natural forests, wood plantations, and ornamental ecosystems. The most important elements of diffusion and infection are rhizomorphs, as well as mycelium, passing through the soil (or by radical contact) from sick to healthy plants, often in an oil stain; infection rarely comes from basidiospores, usually through cut surface.
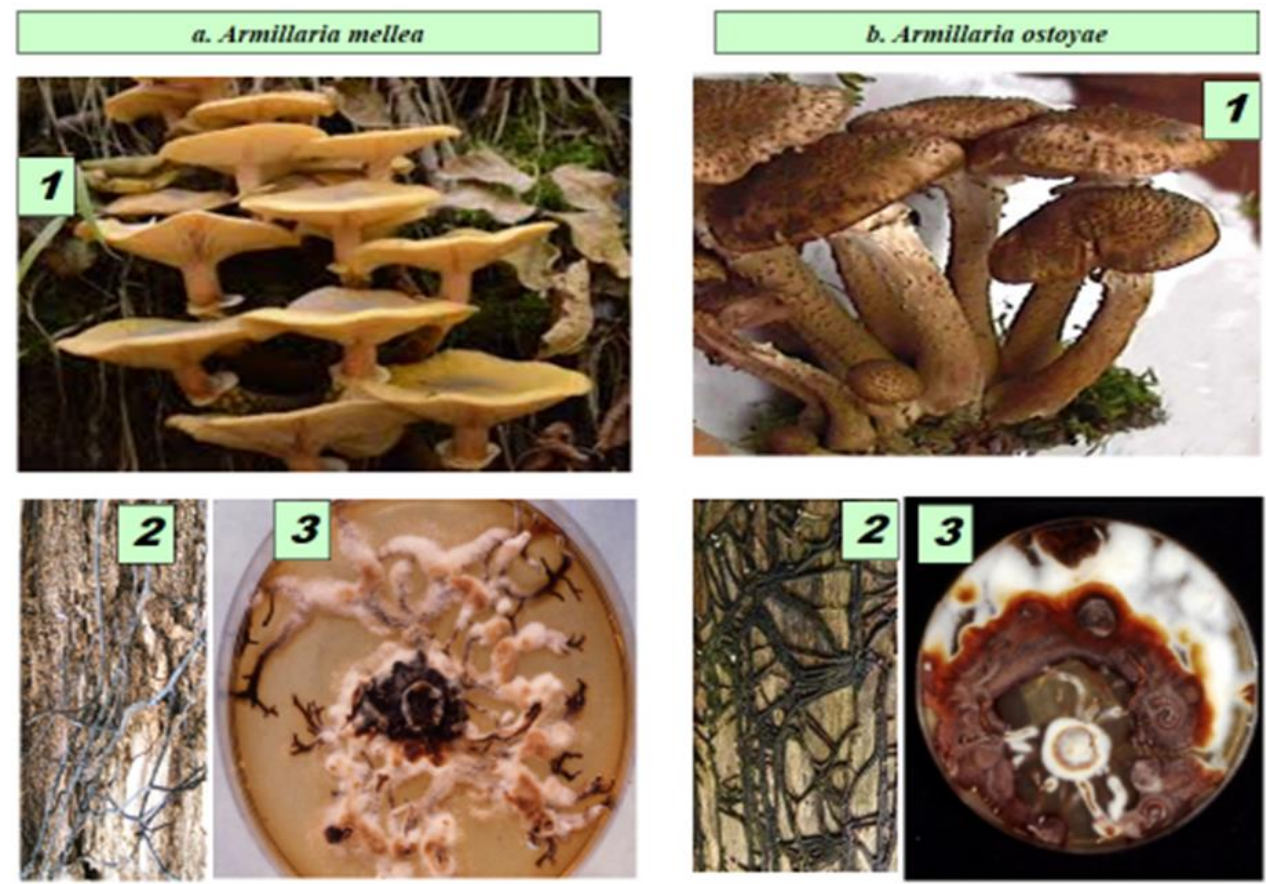

Fig. 1. Basidiomes (1), rhizomorphs (2) and in vitro colonies (3) of Armillaria mellea (a) and Armillaria ostoyae (b).

In the wake of studies on the cariological cycle and the tetrapolar etherotalism of the fungus conducted by Karl Korhonen (Korhonen, 1978) and subsequently by various other researchers, then validated by studies with isoenzymes (Anselmi et al., 1997) and, more recently, by molecular methods, in Italy 5 species of annulate Armillaria have been found: A. cepistipes Velenosky, saprophytes on conifers; A. mellea (Vahl: Fr) Kummer (Figure 1a), weakness parasite, but also primary pathogen, or saprophyte on broad-leaved trees and, less, coniferous species; A. ostoyae (Romagnesi) Herink (= A. obscura (Schaeffer Herink) (Figure 1b), primary or weakness parasite on conifers; A. tabescens 
(Scop.) Emel. (Figure 2b) and A. gallica Marxmüller and Romagnesi (=A. bulbosa (Barla) Kile and Watling) (Figure 2a), weakness parasite or, above all, saprophyte on broad-leaved trees (Vannini and Magro, 1987; Intini, 1988, 1989, 1990, 1997; Anselmi and Lanata, 1989; Tirrò and Rapisarda, 1989; Ippolito et al., 1989; Cellerino et al., 1990; Shaw and Kile, 1991; Guillaumin et al., 1993; Luisi et al., 1996; Sicoli et al., 2002; La Porta et al., 2005).

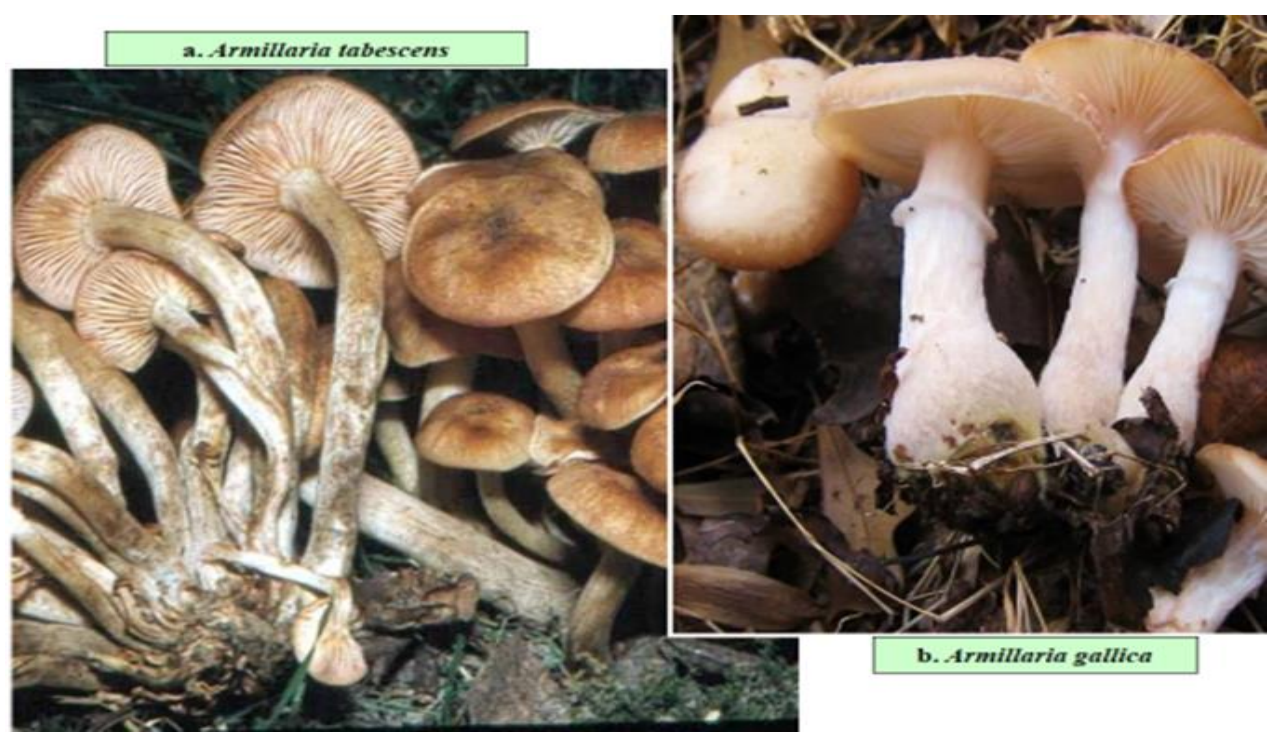

Fig. 2. Basidiomes of Armillaria tabescens (a) and A. gallica (b). (Carpofori di Armillaria tabescens (a) e A. gallica (b).
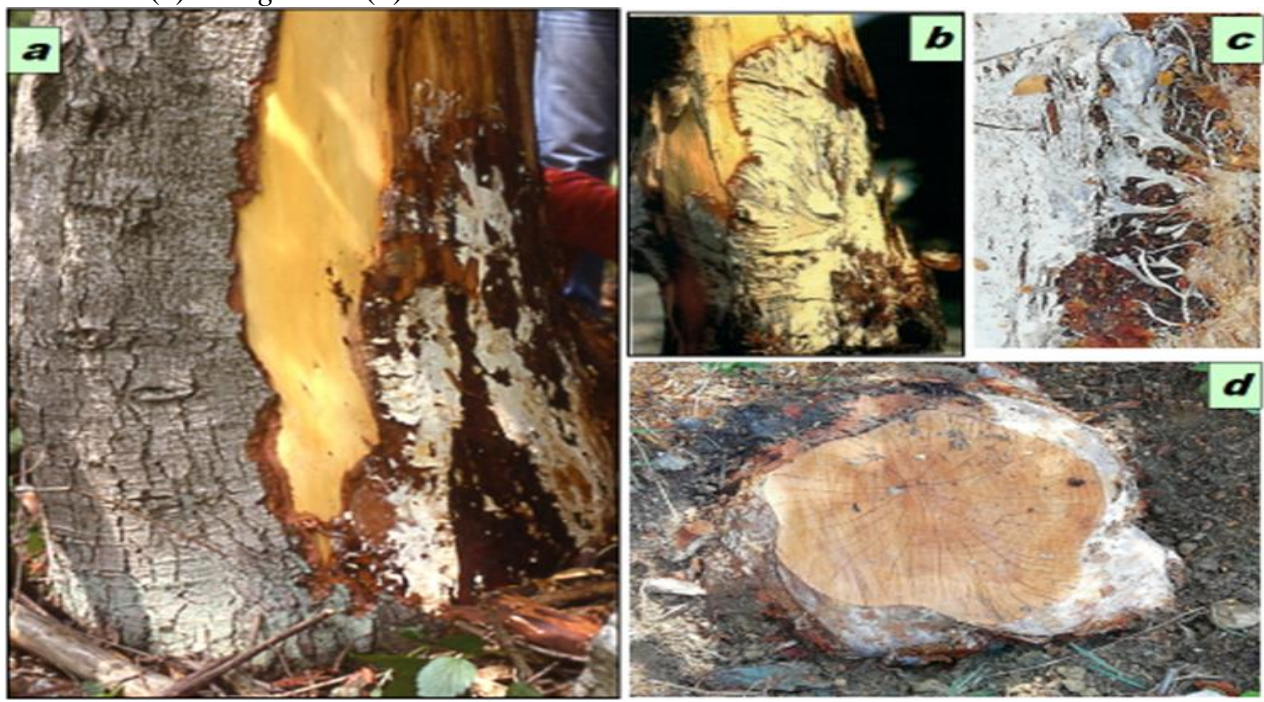

Fig. 3. Cream-white mycelium plaques of Armillaria ostoyae (a-b) and A. mellea (c-d) under the bark of basal part of the trunk of Abies alba (a), Pinus nigra (b) and Prunus armeniaca $(\mathrm{c}-\mathrm{d})$. 
The most systematic territorial studies have involved northern and southern Italy and Tuscany, while various gaps remain regarding the lower part of central Italy, including Latium.

In the past, attacks of Armillaria in our country were complained mainly on orchards and shade trees, generally connected to soil with stagnant water, poorly drained, especially in the presence of high inoculum pressure. In recent decades, particularly in Mediterranean environments, the attacks of the fungus have become increasingly serious everywhere, even in forests, especially in dry areas, in parallel with the increasing phenomena of forest and tree declining, associated with climate change, often without clarity on the role of the fungus on the death of plants (Cellerino et al., 1990; Luisi et al., Eds, 1992; Luisi et al., 1996).

Taking into account the Lazio region, heretofore neglected, in order to provide clarifications on the aforementioned aspects, this note aims to report the results of a series of investigations carried out in the last fifteen years to detect the incidence of the various species of Armillaria in various orchards, wood plantations, forests and ornamental ecosystems of the region and to identify the real predisposing factors for their attacks.

\section{MATERIAL AND METHODS}

The surveys have been conducted over the last fifteen years, on arboreal or shrubby agrarian, forest, or ornamental plants in various areas of the Lazio region, taking into account different stations from sea level to mountain areas, considering various sites per station. For some aspects the observations were carried out in stations already considered by other research projects, such as, for example, those relating to studies on "forest declining" (Figure 4) or on "parasitic attacks in deciduous plantations for valuable wood" (Figure 5).

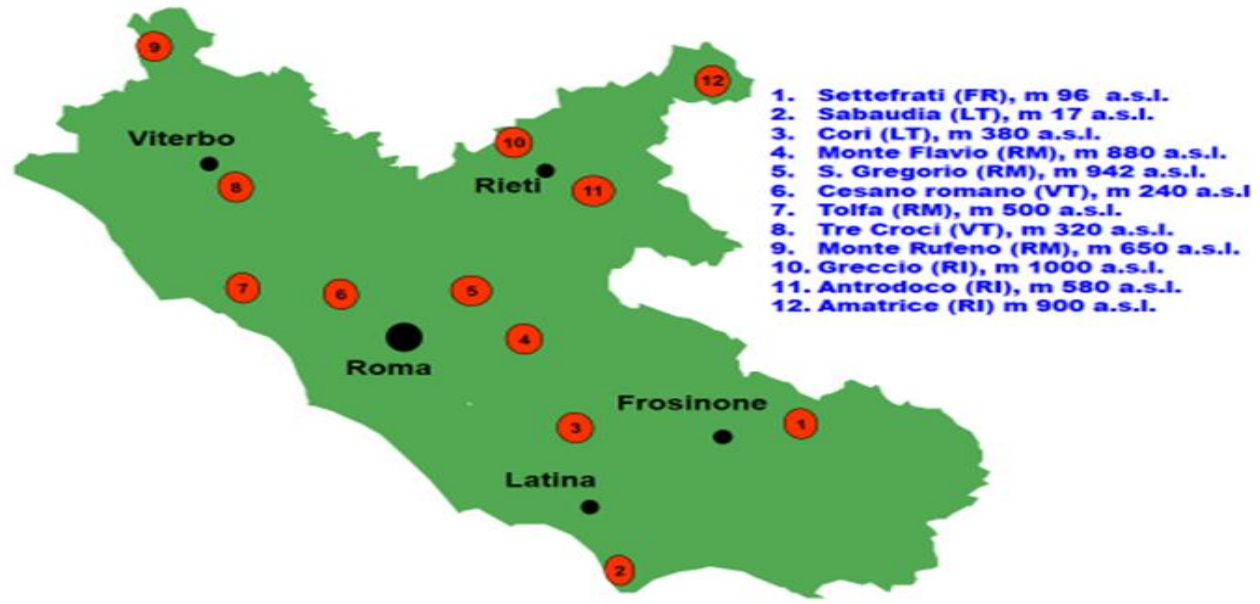

Fig. 4. Stations of the region Latium in which investigations were carried out on the relationship between declining degree of oak forests and attacks of Armillaria species on the relative plants 


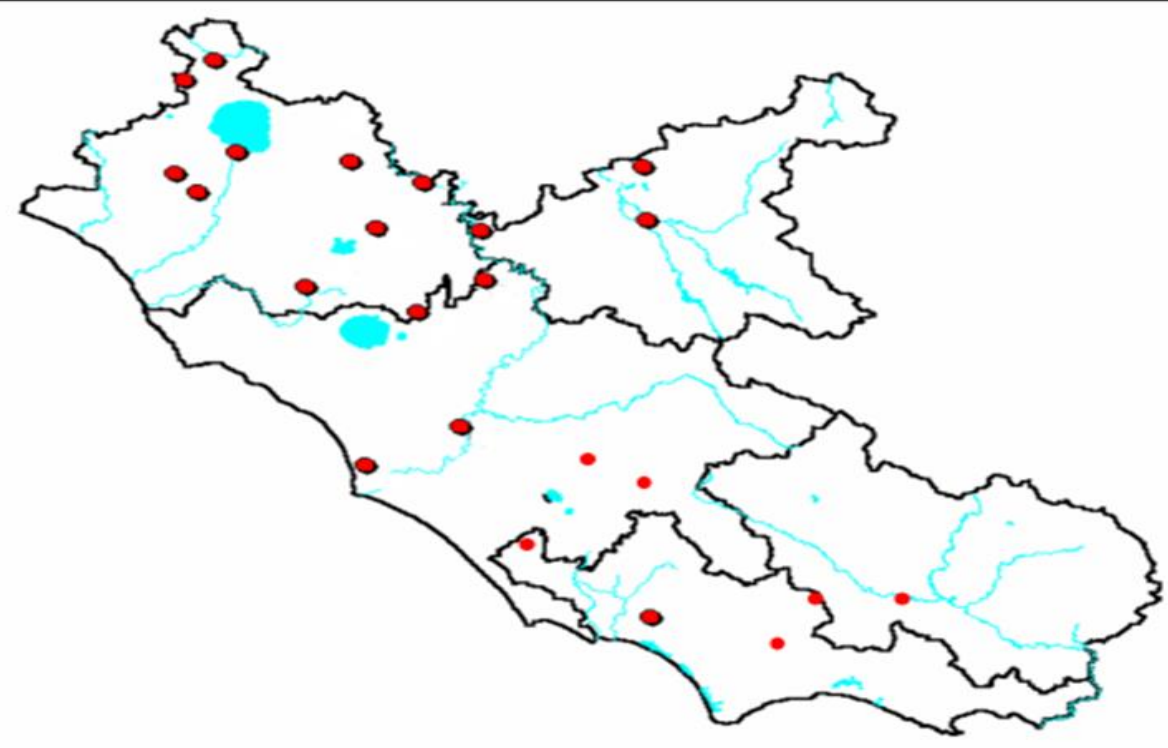

Fig. 5. Stations of the region Latium in which investigations on Armillaria attacks in valuable hardwood plantations were carried out.

Researche was directed at trees and shrubby plants with symptoms of suffering or decay, making observations on the proximal parts of the large roots, and on collar and the basal part of the trunk. In case of presence of Armillaria, for each station the following factors were noted: species, age and development of the affected plants, altitude, exposure, nature of the soil, presence of stagnant water, attacks by other parasites, damage from abiotic factors. In the case of agrarian plantations, the level of agronomic cures towards the plants, in particular fertilization, soil processing and irrigation, the crop preceding the plantation, the density of the plants and the eventual association with other trees or herbaceous crops were also noted. Similar observations were conducted for artificial wood plantations, where the dominance or not of the plants affected was also reported. In the ornamental field, the situation of the plant site, any excess or lack of irrigation, any critical situation that could cause suffering to plants, such as asphalting, cementing, pollution or other soil anomalies, atmospheric pollution, the state of the foliage, have also been recorded. In the case of surveys in the forest, the following additional factors were detected: turn of use, biodiversity, homogeneity or not of the plants; percentage of eventual desiccations to the canopy (declining index); incidence of grazing; presence of dead plants, including those collapsed to the ground. Observations on the development and integrity of mycorrhizae were also occasionally reported.

The identification of the Armillaria species was carried out on the basis of the rhizomorphs and above all the basidiomes appearance (Figures 1-2), and in the event of serious doubts, through observations on the appearance of the 
colonies (Figures 1.3) appropriately made to develop in Petri dishes (Intini, 1988; Anselmi and Lanata, 1989; Anselmi et al., 1990; Shaw and Kile, 1991).

During the processing of the surveys conducted, for some sites the monthly precipitation of the last eighteen years, collected by Meteorological Stations in Latium, has been analyzed.

\section{RESULTS AND DISCUSSION}

On the whole, in about 100 different stations (1500 sites), around 5000 plants apparently at risk of over 50 different agrarian, ornamental and forest species, arboreal or shrubby, were examined.

In ninety of these stations, the presence of Armillaria of four different species was detected: A. mellea (Figure 1a) and A. ostoyae, (Figure 1b) chiefly weakness pathogens, but often as primary pathogen, A. tabescens (Figure 2a) and A. gallica (Figure 2b), predominantly saprotrophs or, rarely, weakness pathogens.

\section{Incidence of the various species.}

Of the four species, A. ostoyae was the least widespread (6 stations), found only on conifers, and in particular in some woods of Abies alba (Figure 3a) and, above all, of Pinus nigra (Figure 6), at altitudes over 700 meters a.s.l.

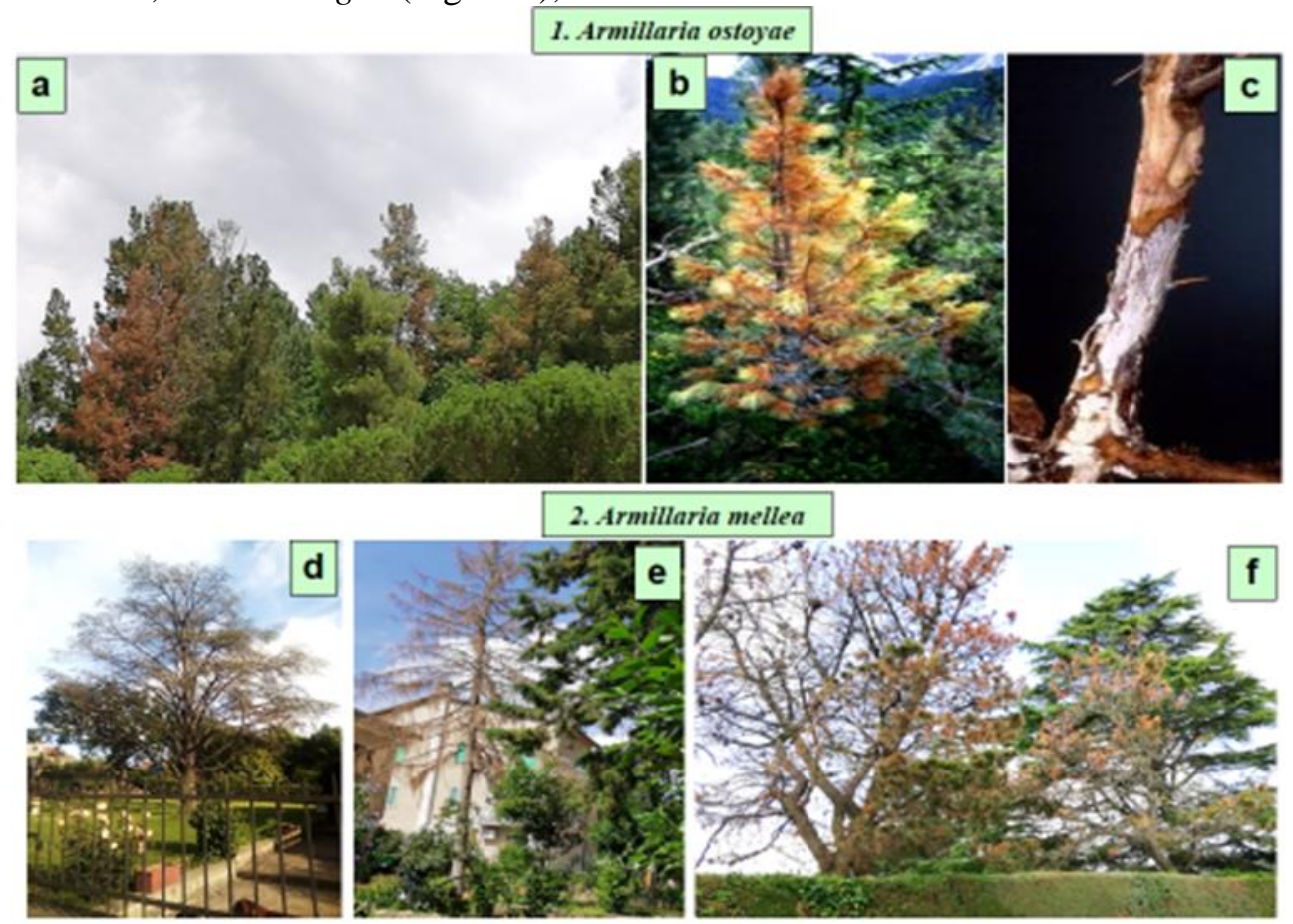

Fig. 6. Attacks of Armillaria on conifers: 1) A. ostoyae on Pinus nigra forest in Terminillo mountains. In b-c, infections on young plant. 2) A. mellea on ornamental trees of Cedrus atlantica (d) and Abies alba (e) incorrectly associated, and of Pinus pinaster attacked by Tomicus (f). 
Its attacks have appeared to affect declining plants by strong drought, high competition with each other, or weakened by attacks of bark beetles. Some attacks have appeared to be associated with Heterobasidion root infections. In case of high inoculum pressure, the pathogen also affected young plants (Figures 6b-c), which soon ended up declining to death. A little more frequent were $A$. tabescens, (Figure 2a), found in 18 stations, with abundant basidiomes but rare rhizomorphs), and, less, A. gallica (Figure 2b), found in 12 stations, but with few basidiomes. These were usually found joined to A. mellea, with saprophytic character, in Quercus woods, either deciduous (Q. cerris, $Q$. pubescens, $Q$. robur, ecc.) or evergreen ( $Q$. ilex and $Q$. suber), on very decaying or dead plants mainly due to "oak decline phenomena" (see below).

The most numerous attacks, however, were ascribed to A. mellea, on broadleaved trees and shrubs, but also on coniferous ones, both on orchards, forests, plantations and ornamental plants, in parks, gardens or shade trees, often as a weakness parasite, but also with evident pathogenic capacity, especially in case of high inoculum pressure. Infections in vineyards (Figure 7a), orchards (fig. 7b-c) or olive groves (Figure 7d) have appeared to be very diversified, depending on the cultivation status of the plant. The well-cultivated plantations were not much affected, except in areas with persistent water stagnation, on old plants or in the presence of old infected stumps of previous plants.
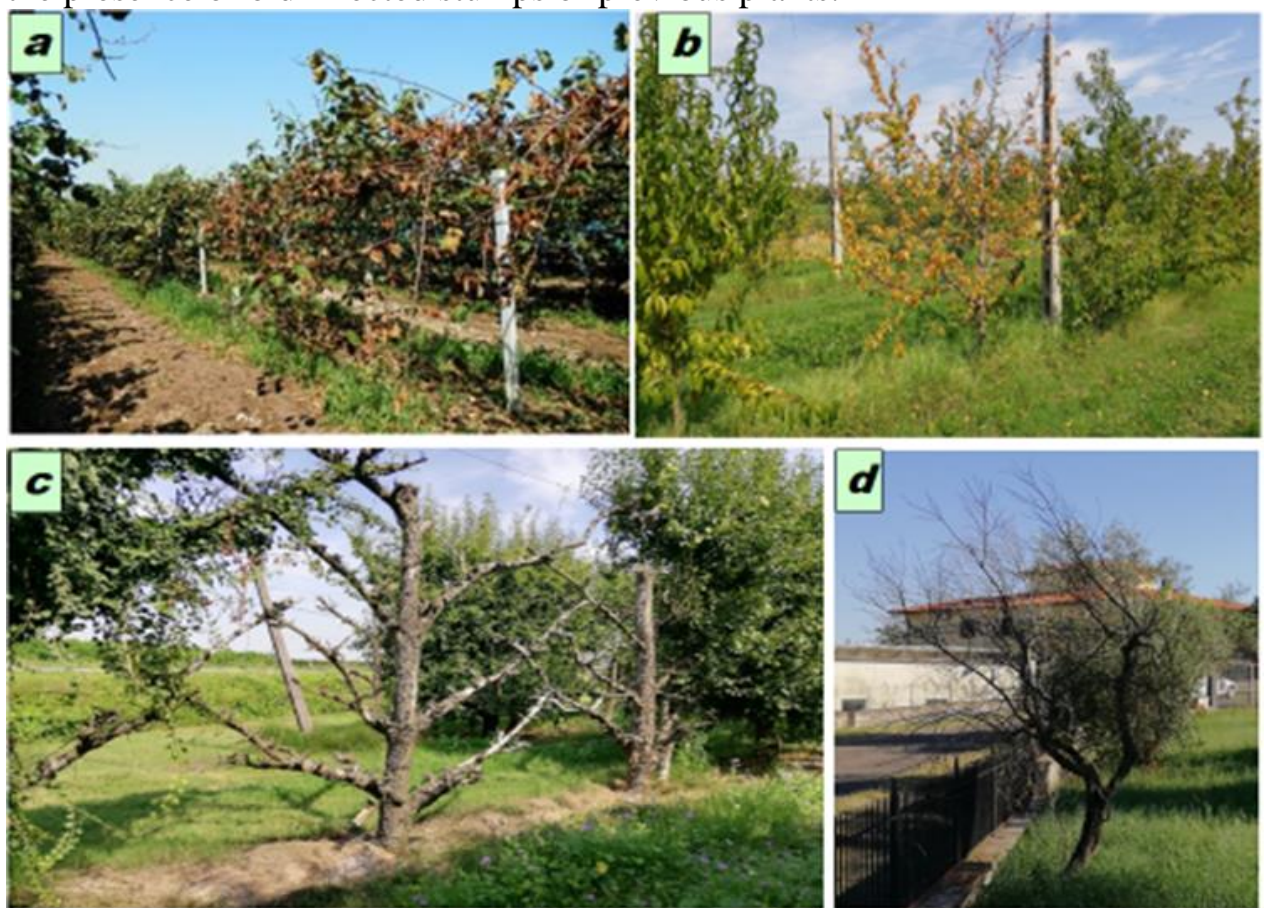

Fig. 7. Attacks of Armillaria mellea on agricultural arboreal plants: a. Vitis vinifera, b. Prunus persica, c. Pirus communis, d. Olea europea. 
On grapevines, the attacks appeared as often confused with those from 'esca disease', much more widespread, and to which it often joins the same plant. Olea europea and Amygdalus communis have been attacked especially when associated with abundantly irrigated crops.

However, the most frequent attacks were found on old plants located in gardens or vegetable gardens, or in plantations little cared for, without sufficient irrigation, often set up and conducted as a hobby, or in abandoned plantations, with reduced reactivity of the plants. Here it would seem that the passing of years, with prolonged summer droughts probably connected with Global Change, played an important role (see below).

Prunus persica (Figure 7b) and Prunus armeniaca (Figures 3c-d), appeared to be the species most recurrently affected, followed in the order by Citrus, Vitis (Figure 7a), Pyrus (Figure 7c), Malus, Actinidia, Corylus, Prunus domestica and, finally, by Castanea and Diospyros.

More articulated were the attacks of A. mellea on forests, wood plantations (Anselmi, 2001) and ornamental plants, in their various types (parks, isolated shade trees, tree-lined roads or waterways) and to the most diversified predisposing factors. Some are common to agrarian contexts, while others are much more complex, in any case connected to the environmental conditions, often extremely critical, in which the aforementioned ecosystems are found. Here the attacks were conditioned, in addition to the factors previously indicated for the other species, also by incorrect plant associations (Figures 6d-e), by particular anomalies of the soil, such as excessive compaction for grazing (in forest) or asphalting, cementification (Figure 8b) or presence of pollutants, by damage from other parasites (Figure 6e) or abiotic factors, especially prolonged and repeated drought, linked to climate change.

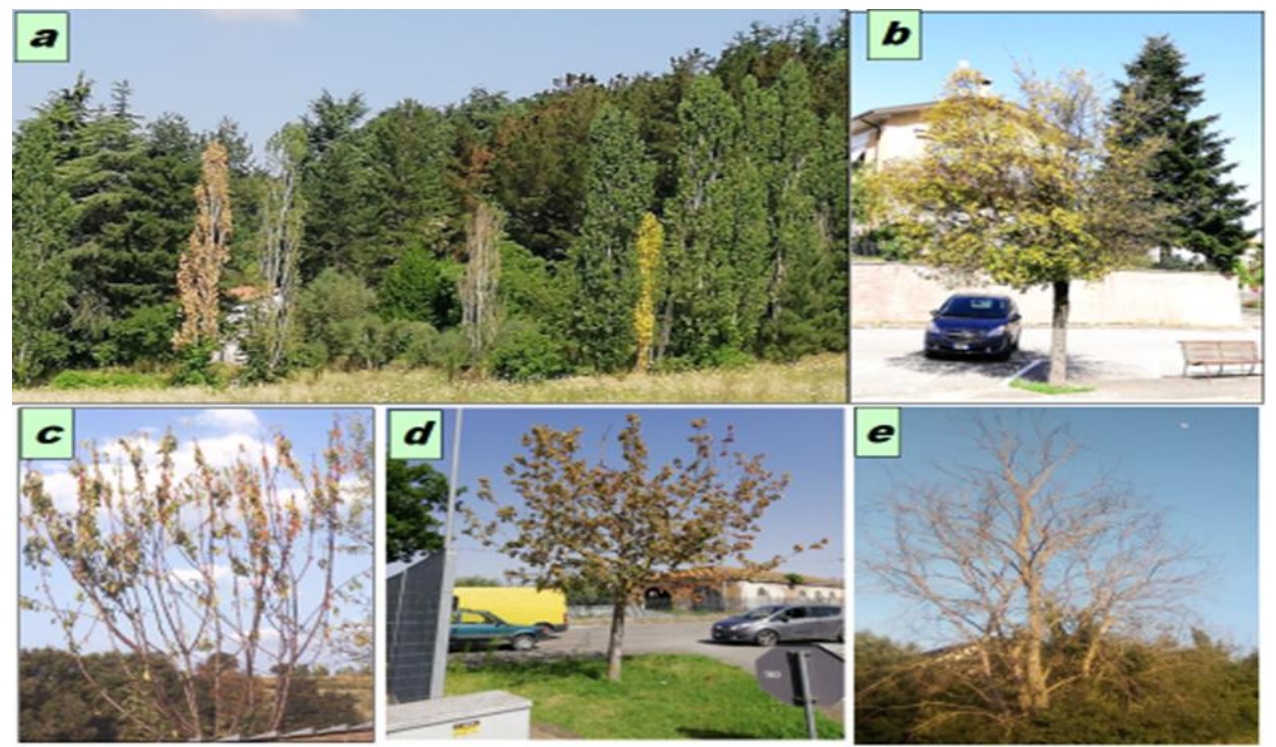

Fig. 8. Attacks of Armillaria mellea on forestal broadleaved trees: a. Populus nigra; b. Quercus ilex; c. Prunus avium; d. Acer campestris; e. Robinia pseudoacacia. 
With respect to the past, however, our findings have shown a certain resurgence of the attacks of the fungus, particularly evident in forests (Figure 9), plantations or shade trees (Figures $8 \mathrm{a}-\mathrm{c}-\mathrm{d}-\mathrm{e}$ ) affected by the so-called "declining phenomenon" triggered by the strong aridity (Figure 10) related to aforementioned Climate change. These recrudescences have also been highlighted by the copious autumn productions of basidiomes at the base of the affected plants or on the relative stumps after the abatement or collapse on the ground.

Among the many species involved, those on which we have more frequently detected colonization of Armillaria to the collar are attributable to the genera (in order) Populus (Figure 8a), Quercus (Figure 9), Salix, Fagus, Robinia (Figure 8e), Sambucus, Carpinus, Acer (Figure 8d) , Betula, Prunus (Figure 8c), Morus, Ligustrum , Eucalyptus, Fraxinus, Celtis, Juglans, Laurus, etc., and, among the shrubs, Spartium, Prunus laurocerasus, Viburnum timus, Syringa vulgaris. Attacks on Platanus, Alnus, and especially on Tilia and Ailanthus (Sciré et al., 2011) appeared as quite rare.

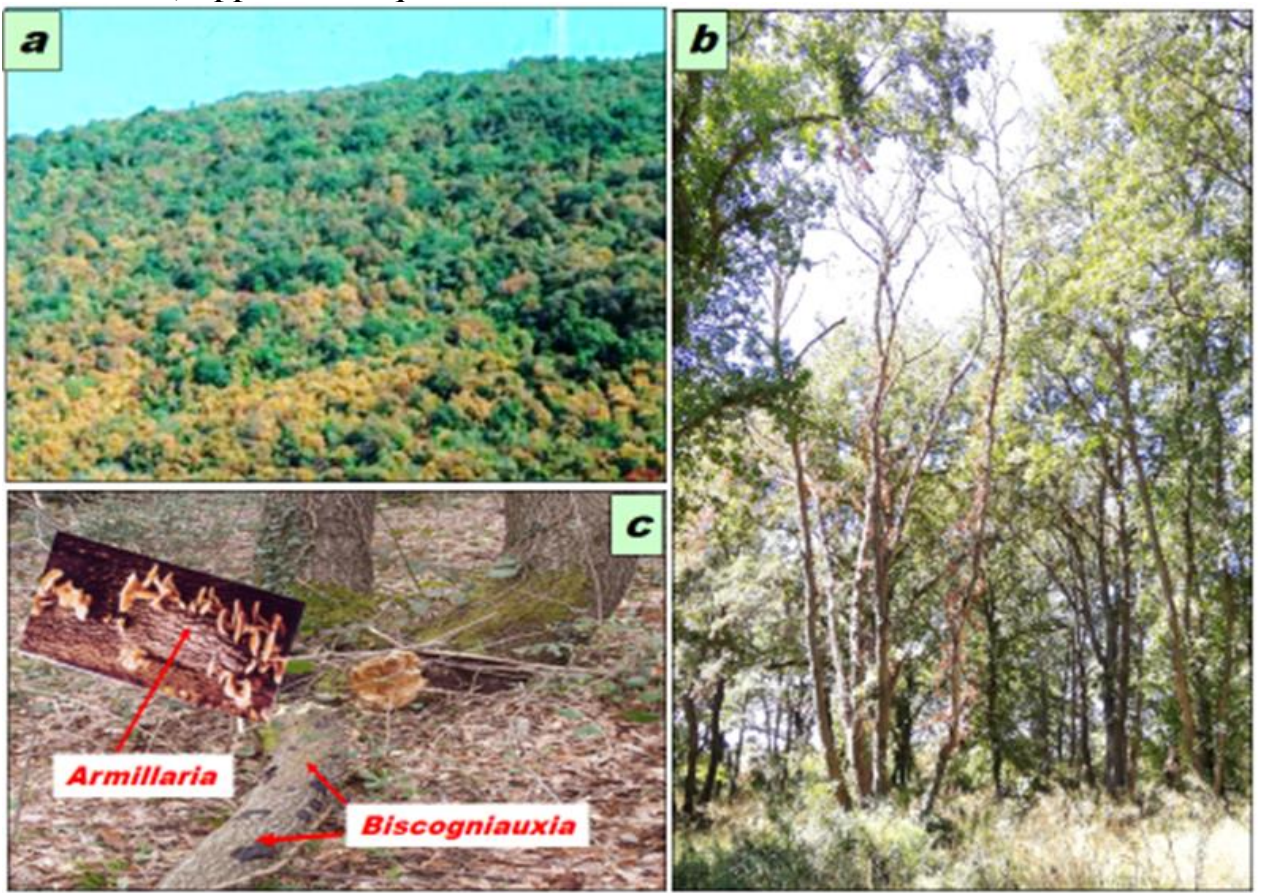

Fig. 9. Typical symptoms of the oak declining generally accompanied by attacks of Armillaria spp: Quercus cerris plants with strong yellowing of the foliage (a); dying plants (b) and trunks already fallen to the ground with stroma of Biscogniauxia mediterranea and basidiomes of Armillaria (c).

In many of these plants we have often noticed a degeneration of ectomycorrhizes (Pirazzi et al., 1996), with the death of numerous mycorrhizal apices (Figure 11), which generally accompanies a real alteration of the useful microflora of the soil (Ambrosoli et al., 1995). It is presumable that these 
phenomena of suffering of the symbionts and of the useful microflora in the soil reduce their antagonistic capacities towards Armillaria, favoring its aggressiveness and attacks.

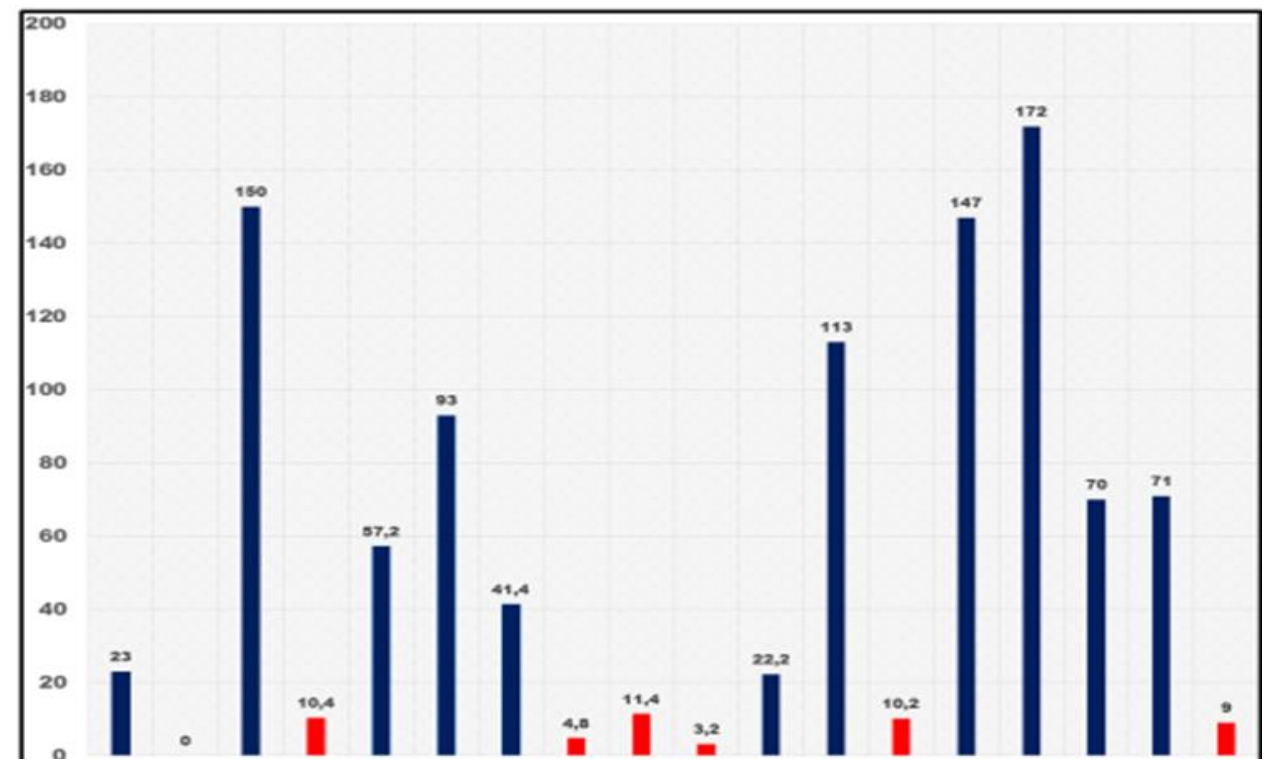

Fig.10. Cesano of Roma. Precipitations in millimeters in the period June-August of the last 18 years; in red the years considered to be very dry.
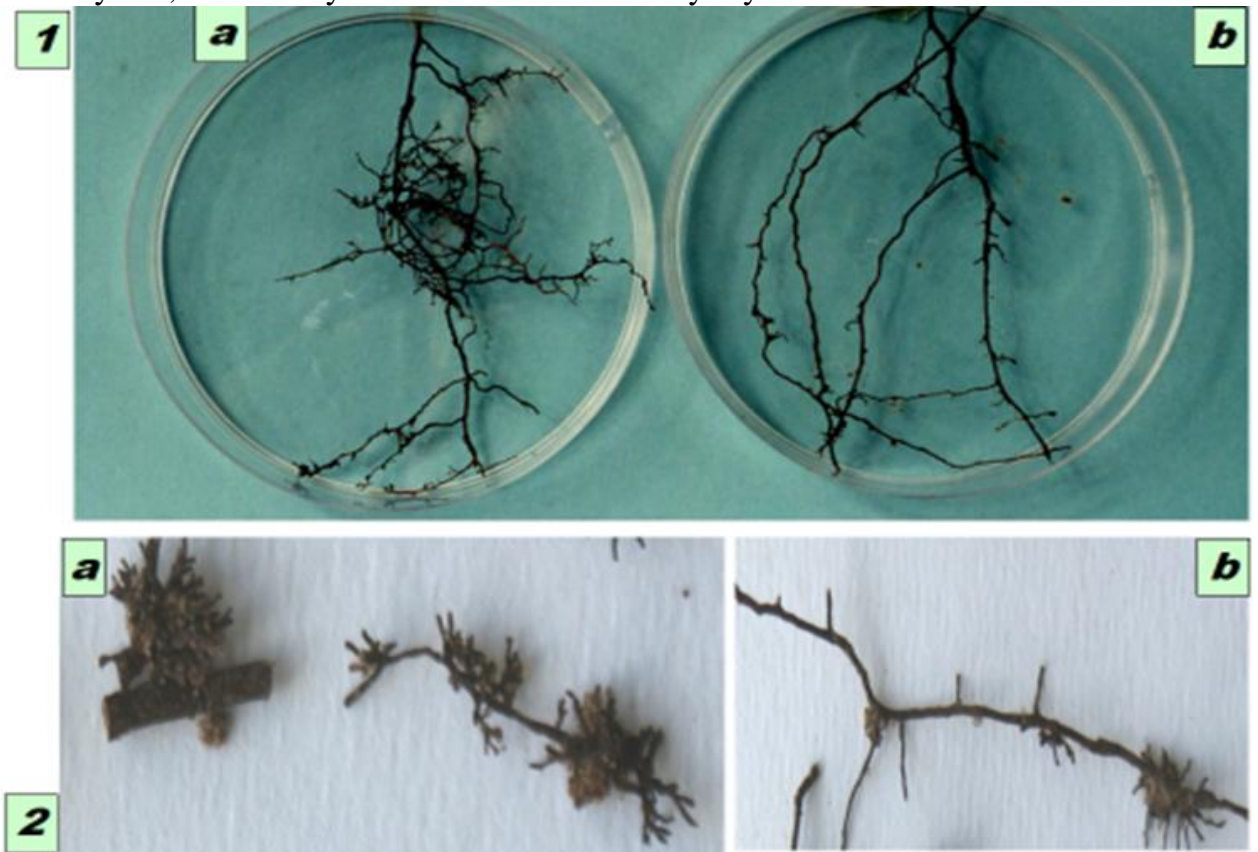

Fig.11. Mycorrhizae on Fagus sylvatica (1) and Pinus pinea (2) roots related to healthy (a) and declining (b) plants (from Torta et al., 2016). On some of these, attacks by Armillaria mellea have been detected. 


\section{Predisposing factors.}

From the foregoing analysis it emerges that our investigations have on the whole highlighted aconsiderablenumber of factors that predispose the attacks of Armillaria, some of which are linked to a significant worsening of the state of health of the plants in the last decades. The 10 most recurrent factors that our findings have shown to be linked to the attacks of A. mellea, but which also include those related to the other species of the pathogen, are briefly analyzed below.

1. High inoculum pressure. Our investigations confirmed the important role of high inoculum pressure, especially if linked to accumulations of mycelium or rhizomorphs in the ground due to the presence of infected plants or of residues of old infected stumps (Figure 12a).
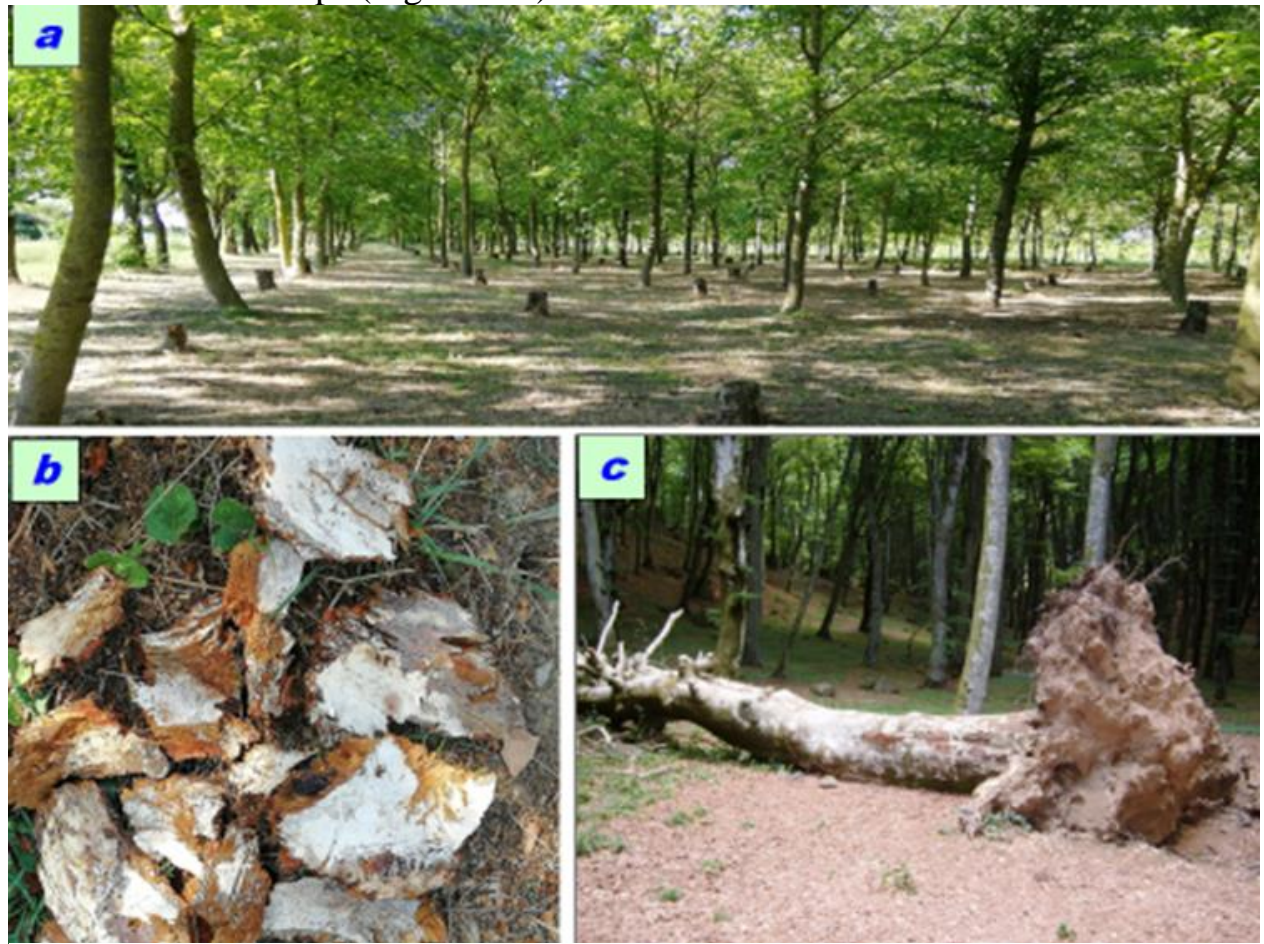

Fig.12. Some predisposing factors of Armillaria attacks: a. Thinning of a valuable hardwood plantation without removing the stumps: these will be easily colonized by the fungus and will act as an inoculum mass. If reduced in fragments (b), they will favor the diffusion of the inoculum in nearby areas. In c: old plant of Fagus sylvatica collapsed on the ground for attacks by Armillaria mellea in the very old beech forest of the Cimini Mountains.

If a tree is killed, the entire root system may become inoculum. In species in which the Armillaria is a primary pathogen, such as A. mellea and A. ostoyae, infection with a high level of inoculation generally resulted in rapid death even if the plants were vigorous before the attack, especially if young, close to relatively large food bases such as stumps. With stumps colonized by the fungus it would 
therefore be advisable to extract the whole stump and the infected material. On the other hand, their crushing with a shredding machine should be avoided because the numerous resulting fragments of infected wood (Figure $12 \mathrm{~b}$ ) could be moved with the processing of the soil, potentially acting as new sources of inoculation.

2. Senescence of the plants. Undoubtedly plants that are too old, often compromised by the most varied factors, are not very reactive to pathogens and therefore more prone to encounter attacks of Armillaria, which are generally endemic and therefore always lurking. The phenomenon has emerged as particularly evident in various old forests (Figure 12c), parks or ornamental trees where, for historical, environmental and landscape reasons, we tend to conserve even very old plants. Truthfully, in some woods, especially if very old, the attacks of Armillaria are part of the natural balance of the ecosystem, participating slowly in the process of elimination of old, weaker plants, and creating spaces for a natural forest renewal.

3. Water stagnation in the soil. An excess of water in the soil on the one hand favors the fungus, enhancing its vitality and spread, while on the other creates stress to the plants, making them less reactive. Obviously, these stagnations appeared as particularly frequent in compact soils, in the valleys, in the floodplains, and in any case where soil drainage is poorly treated.

4. Incorrect associations of the plants. Even without water stagnation, which is always deleterious, a lot of water in the ground appeared anyway to favor the attacks of Armillaria towards those tree and shrub species that suffer water abundance, when they are affiliated to meadows or other species subject to intense irrigation, as it often happens in parks and gardens. The most recurrent cases concerned the species with xerophilic habitus, such as Quercus ilex, $P$. pinea, P. pinaster, P. halepensis, Olea europea (Figure d), Laurus nobilis, Cupressus spp. and various other species of the Mediterranean scrub, as well as species of mountainous origin that avoid excess water, such as Abies alba (Figure 6e) and Picea abies, usually residual of Christmas trees, and especially the different species of Cedrus (Figure 6a), one of the genes that are most affected by the pathogen. The abundant irrigations, favorable for the lawns or other herbaceous plants, but also for the diffusion of the pathogen, induce the tree plants not to deepen the root system. It follows that at the first interruption of irrigation (e.g., for rupture of the irrigation system) occurring in the summer season, the aforementioned plants quickly go into water shortages stress, favoring the attacks of Armillaria, ready to hit the suffering plants.

5. Attacks by other parasites. Many of the Armillaria attacks we found appeared as a result of the weakening of plants from attacks by other parasites, such as Graphium on Ulmus, Tomicus (Figure 6f) and/or Spaeropsis sapinea on Pinus, Cydalina on Buxus, Cytospora on Carpinus, Cryptosphaeria (in short rotation) and Agrilus on Populus. The most recurring cases have concerned Mediterranean pines, which, in recent years, have been strongly attacked by Tomicus due to strong water shortages, such as that of 2017: about $15 \%$ of dead 
or dying plants showed attacks by A. mellea. As for the elm, decimated in recent years by tracheomycosis, while young recurs only rarely have shown the presence of Armillaria, the older plants, with a slower course of tracheomycosis, were colonized in at least $10 \%$ of the subjects.

6. Declining of the plants from climatic changes. A strong upsurge of the attacks of Armillaria appeared evident following the decline of the forest plants that has occurred in the last decades, due to prolonged and repeated summer droughts connected with well-known climatic changes (Cellerino et al., 1990; Luisi et al. Eds, 1992; Anselmi et al., 1998).

These have appeared exalted in dry soils or in very dense plantations, with plants in strong competition among themselves, in which the submissive subjects, less reactive, are particularly susceptible to the parasite. In Latium, the phenomenon was first highlighted in the forest, in particular on Quercus (Figure 9) and, to a lesser extent, on Pinus nigra, and in artificial wood plantations, especially Populus spp or Prunus avium (fig. 8c), but also in parks and other ornamental trees, as well as in some orchards which were not irrigated.

Predisposed by various factors, both intrinsic to the plant (genetic potential, senescence, etc.), or extrinsic, i.e. connected with environmental (e.g., not suitable soil) or anthropic (improper cultural interventions, excessive pasture, etc.) problems, the phenomenon is generally triggered by prolonged and repeated water shortages and results in the aggression of various weakness parasites, which progressively increase the pathological state of the plant until its death. Among these parasites an important role is often played by the Armillaria species, usually in combination with various secondary corticicolous agents, both fungal (e.g., among the most evident in Mediterranean areas, Biscogniauxia on Quercus (Figure 9), Sphaeropsis on Pinus), and insects (Tomicus, Ips, Agrilus, etc.). In recent years there has been a marked worsening of the phenomenon due to the severe summer droughts of 2001, 2003, 2007, 2008, 2009, 2012 and 2017 (Figure 11), which gave rise to an evident resurgence of the attacks of Armillaria species. This in fact, endemic everywhere, during the rainy periods reaches with the rhizomorphs the various plants, apparently harmless, to be unleashed on those rendered less reactive by the aforementioned stresses, probably also due to a strong suffering of mycorrhizae (Pirazzi et al., 1996; Torta et al., 2016) (Figure 10) and of the antagonist microflora (Ambrosoli et al., 1995), which are therefore less in their braking action towards the pathogen (see above).

The phenomenon was particularly severe in many oak forests, especially Quercus cerris (Figure 9), not very tolerant of drought. In the oak woods with declining phenomenon, A. mellea, A. gallica and A. tabescens are often present together, usually on plants already killed or weakened by other agents. The incidence of the three species was correlated with the degree of forest declining (Table 1): while A. gallica and A. tabescens were found only in woods with high intensity of the phenomenon, A. mellea appeared almost everywhere, but with increasing incidence with the severity of declining 


\begin{tabular}{|c|c|c|c|c|c|}
\hline \multirow{2}{*}{\multicolumn{2}{|c|}{ Stations }} & \multirow{2}{*}{$\begin{array}{c}\text { Dead } \\
\text { plants } \\
\%)\end{array}$} & \multicolumn{3}{|c|}{ Incidence of Armillaria } \\
\hline & & & mellea & gallica & tabescens \\
\hline Antrodoco (RI) & $m 600$ a.s.L. & 0,5 & - & no & no \\
\hline $\operatorname{Cori}(L T)$ & $m 380$ a.s.t. & 0,5 & - & no & no \\
\hline S. Gregorio (RM) & m 9.42 a.s.l. & 1 & - & no & no \\
\hline Greccio (RI) & m 900 a.s.l. & 2 & - & - & no \\
\hline M. Flavio (RM) & $m 880$ a.s.t. & 2 & - & no & no \\
\hline Amatrice (RI) & m 550 a.s.l. & 3 & - & - & - \\
\hline Settefrati $(F R)$ & $m 800$ a.s.l. & 5 & + & - & no \\
\hline Sabaudia (LT) & $m 17$ a.s.t. & 8 & + & - & - \\
\hline Cesano (RM) & $m 250$ a.s.l. & 17,5 & ++ & ++ & ++ \\
\hline Tolfa $(R M)$ & m 610 a.s.l. & 23 & +++ & ++ & + \\
\hline Monte Rufeno (V7 & T) $m 650$ a.s.t. & 30 & +++ & + & ++ \\
\hline Tre Croci (VT) & m 380 a.s.L. & 32 & +++ & ++ & ++ \\
\hline
\end{tabular}

Tab.1. Incidence of the various species of Armillaria on plants of Quercus cerris affected by different degrees of declining: no: none; - rare; +: modest; ++: discrete; +++: high.

Strong water shortages, especially if combined with high summer heat, have in many parts triggered tree declining and related attacks by A. mellea even in isolated plants or groups of plants, especially along roads or in urban trees (Figures 8a-c-d-e).

7. Excessive pasture. In some old beech or oak woods (e.g., Lucretili and Tolfa mountains), the excessive trampling by grazing animals, particularly cattle, has created a certain suffering to the plants and has predisposed them to the attacks of pathogens of weakness, including Armillaria.

8. Poor adaptation of the host species to the site. Species that are not adapted to the site where they grow tend to be more prone to suffering and are therefore more susceptible to Armillaria attacks. Quercus cerris, for example, a plant which in the past was appropriate for the production of railway sleepers, was also widespread in areas not very suitable, instead of Quercus pubescens. Upon close observation, this species has proved to be the most susceptible to declining phenomena (see above) due to stress from water shortages, and also the most frequently prone to Armillaria attacks.

9. Damages by other stresses. Our investigations have shown various other examples of stress that, by causing declining and death of the interested plants, have favored the attacks of Armillaria. The most recurring cases are listed below: damage from salt antifreeze, as verified for Robinia and also Ailanthus 
grown along mountain roads, where the snowplows more easily end up accumulating such pollutants under the plants; damage from saltiness as it occurs for some coastal pine forests; excessive asphalting or cementation of the soil around the trunk (Figure 8d), with water scarcity or root asphyxia, as it often happens in urban areas.

10. Specific susceptibility. At least with reference to A. mellea, despite its being an extremely polyphagous pathogen, our results confirmed (Raabe, 1979; Shaw and Kile, 1991) its greater aggressiveness on some species rather than on others. For example, in a plantation of different forest species of valuable wood, made up after an old vineyard affected by A. mellea, the incidence of the fungus seemed significantly to decrease on the various species in the following order: Prunus avium, Alnus cordata, Fraxinus ornus and Juglans regia. The 10 plants of Juglans nigra which were present, even in the middle of the affected plants, were not damaged at all.

Likewise, in a garden also built on land that had hosted an old abandoned vineyard affected by A. mellea, the tree species planted there at random ended up dying from attacks of the pathogen with the following decreasing "intensity": peach, plum, cherry laurel, privet trees, stone pine, holm oak.

In the orchards, while peach and apricot seem to be the most frequently affected species, chestnut and persimmon would be the least predisposed. However, in most cases, the apparent resistance of the host species to Armillaria is indirect, because it derives from the tolerance of that species to some predisposing factor. In the decline of the oak forest, for example, the greatest attacks of Armillaria on Q. cerris compared to those on $Q$. pubescens or $Q$. ilex are caused by its greater suffering due to shortage of water in the soil (see above).

It is worth mentioning that until now in Latium we have never encountered attacks by Armillaria on Ginko biloba, Catalpa styraciflua, Juglans nigra, Paulonia tomentosa, even when they were near sick plants.

\section{Discussion}

Our investigations, in addition to finding early evidence of the presence of A. ostoyae in the Latium region, have highlighted a certain resurgence of the attacks of Armillaria spp. in the last period, in particular on forest and ornamental plants, following the reduced reactivity due to the serious declining phenomena linked to recent climatic changes. Though in a way which is not totally clear, it seems that similar phenomena have interested, and could even more interest, even the orchards, especially poorly cultivated ones. It is not excluded that these outbreaks are destined to increase, also because the measures to combat the parasite are still complex and not always effective (Cellerino et al., 1990; Anselmi, 1992; Guillaumin et al., 1993; Anselmi et al., 1998; Mazzaglia et al., 2001). In fact, until now, no chemical fight intervention has offered good control of the attacks of Armillaria; moreover, their prevention is difficult because the fungus is very common in woody debris in the soil, boasts a wide range of guests and presents a non-specific model of parasitism. 
Nonetheless, some precautions, preventive strategies or eradicating interventions can prevent or limit the attacks or reduce damage.

In artificial plantations, the most important strategies for the protection of orchards, wood plantations and ornamental trees consist in: planting suitable plants; removing the stumps and infected roots from the ground, thereby denying the fungus great food bases; promoting a good vigor of the plants through adequate irrigation (without stagnation), fertilization and pruning; and minimizing stress, also promoting the development of antagonistic organisms. In the establishment of new plantations, it is essential to choose species that adapt to the site and plants free from pathogenic attacks or from mycelium or rhizomorphs in earthen bread (certified plants). The physical removal of the inoculum involves the removal of diseased trees, the eradication of the stumps (no chopping), the destruction of the roots and the mixing of the earth up to a suitable depth, trying to bring to the surface as many fragments of roots as possible. In the case of circumscribed attacks in progress, suitable trenches sprinkled with lime or copper, or coated with plastic and refilled again, may represent excellent obstacles to isolate the infected area from healthy neighboring plants. On plants of great rhyzogenic capacity (for example, old olive trees) or of great value and development, when the attack is not too degenerate, it is often better to try the rehabilitation from the attacks by removing the soil around the collar and the buttresses of the big roots, scraping the tissues invaded by the mycelium and disinfecting the wounds with copper salts. The value of orchards, wood plantations or ornamental plants generally justifies the costs necessary for the aforementioned treatments, which however allow a valid form of defense against the pathogen.

Some suggest using biological control methods with products based on Trichoderma harzianum or fertilizers containing mycorrhizal products, on whose real effectiveness any further verification would be appropriate.

In extensive forests, it could be necessary to pursue an adequate distribution of available water and of the trophic resources among the components of the wood, thereby reducing as much as possible the radical competition among the plants. This would allow them to maintain greater vegetative vigor and therefore less susceptibility to attacks by weakness parasites. Partial cut or thinning can also increase host vigor and root resistance to the pathogen. In many areas it seems advisable to replace species with high climaticstationary needs, which are therefore more vulnerable, with others being more tolerant: $Q$. cerris, for example, could be profitably replaced by $Q$. pubescens. In any case, maintaining good biodiversity through careful forest management ensures better tolerance of plants to biotic and abiotic stresses and consequently to Armillary attacks. Finally, the distribution of the pasture in proportion to the area and the production capacity of the forest could reduce the damage due to the constipation of the land and the bite of animals. This, in addition to improving the vegetative conditions of the forest, would favor the natural renewal of the plant species in the area. 


\section{CONCLUSIONS}

Our research has shown a strong diffusion of the various species of Armillaria in Latium, with damages of particular importance by A. ostoyae on the coniferous forests, and above all A. mellea on the most varied host species and related ecosystems. It is likely that such recent discoveries concerning this region be also attributed to many other areas of our Country and of the Mediterranean in general. The evident resurgence of the pathogen predisposed by the increasing stress and by the declining of the plants - generally attributable to an increasingly intense anthropic pressure and above all to more and more frequent, prolonged and repeated droughts linked to climate changes - suggests an increasingly worrying future scenario.

In order to cope with these outbreaks, it could be useful to follow simple and effective control measures, which are currently unavailable. For these reasons we believe that, in addition to putting into practice every possible strategy aimed at stopping the Global changes phenomenon, it would be necessary to intensify the studies on the control measures against this pathogen, in particular the biological one, based on the antagonists and on the good mycorrhization of the plants.

\section{REFERENCES}

Ambrosoli R., Anselmi N., Cellerino G.P., Ozino O.I., 1995. Rhizospheric mushrooms in beech woods affected by different declining degrees. (Funghi rizosferici in faggete interessate da diversi gradi di deperimento). Atti Seminario CNR Raisa: "Funzionalità dell'Ecosistema Faggeta". Ed. Accademia Italiana Scienze Forestali, Firenze, 259-270.

Anselmi N., 1992. Studies on biological control against Armillaria spp (Studi per interventi di lotta biologica nei confronti di Armillaria spp). Atti Convegno MAF Piante Forestali: Avversità biotiche e prospettive di controllo biologico ed integrato, Firenze, 141-150.

Anselmi N., 2001. Main diseases in high-quality hardwood industrial plants. (Principali malattie negli impianti industriali di latifoglie di pregio). In: Aspetti sanitari e gestione del patrimonio forestale. Ed. Ragazzi, Annali Accademia Italiana di Scienze Forestali, XLIX - L, 79-89.-

Anselmi N., Lanata F., 1989. Distribution and behavior of Armillaria species found in northern Italy. (Distribuzione e comportamento delle specie di Armillaria riscontrate nell'Italia settentrionale). Micol. Ital., 3, 67-70.

Anselmi N., Bragaloni M., Cellerino G.P., 1997. Identification of european Armillaria species by analisys of isozyme profiles. Eur. J. For. Path., 27: 147-157.

Anselmi N., Cellerino G.P., Moriondo F., 1998. The phytopathological situation of the forest heritage in Italy. (La situazione fitopatologica del patrimonio forestale in Italia). Atti $2^{\circ}$ Convegno Nazionale di Selvicoltura, Venezia. Ed. Consulta Nazionale Foreste e Legno, vol. 3, 249-291. 
Anselmi N., Lanata F., Sanguinetti G., 1990. Research on the techniques of identification of Armillaria species. Proceedings of $8^{\text {th }}$ Congress Mediterranean Phytopathological Union, 34-37.

Cellerino G.P., Anselmi N., Esposito L., 1990. Oak declining in Campania: problems, related fungal agents, attempts at silvicultural interventions. (Deperimento delle querce in Campania: problematiche, agenti fungini connessi, tentativi di interventi selvicolturali). Atti Convegno "Problematiche fitopatologiche del genere Quercus in Italia", Firenze, 1920 Novembre, 63-77.

Guillaumin J.J., Mohammed C., Anselmi N., etc., 1993. Geografical ditribution and ecology of the Armillaria species in western Europe. Eur. J. For. Path., 23, 321-341.

Intini, M. G. 1988. Contribution to the knowledge of Italian Agaricales. Guide to the recognition of the Armillaria lignicole. (Contributo alla conoscenza delle Agaricales italiane. Guida al riconoscimento delle Armillaria lignicole. - Micol. Veg. Medit. 3 (1): 49-72.

Intini M.G., 1989. Species of Armillaria in Italy. Proceedings of the 7th International Conference on Root and Butt Rots of Forest trees, Vernon and Victoria, B.C., Canada, 355-363.

Intini M.G., 1990. Notes on the genus Armillaria in Italy. (Note sul genere Armillaria in Italia). Inform. Fitopatol. 4: 51-55.

Intini, M. G., 1997. Armillaria cepistipes and A. gallica (Agaricales, Tricholomataceae) in Italy. Bocconea 5: 861-866.

Ippolito A., Traversa E., Lima G., De Cicco V., 1989. The fibrous root rot of citrus fruits in Puglia and Basilicata and the cultivation characteristics of the pathogen. (Il marciume radicale fibroso degli agrumi in Puglia e Basilicata e caratteristiche colturali del patogeno). Micol. Ital., 3. 143148.

Korhonen, K. 1978. Interfertility and clonai size in the Armillaria mellea complex. Karstenia 18: 31-42.

La Porta N., Grillo R., Korhonen K., 2005. Interaction between different species of Armillaria and Heterobasidion from Italian Alps forests. Proceedings of XXII IUFRO World Congress, Brisbane, International Forestry Review, 7 (5), 246.

Luisi N., Lerario P. and Vannini A., (Eds) 1992. Proceedings of International Congress "Recent advances in studies on oak decline". Selva di Fasano (Brindisi), $541 \mathrm{pp}$.

Luisi N., Sicoli G., Lerario P., 1996. Observations on Armillaria occurrence in declining oak woods of southern Italy. Annales des Sciences Forestiéres, 53: 389-394.

Mazzaglia A., Anselmi N., Vannini A., Esposito L., 2001. Root rots in the forests of Campania attempts at biological and integrated control. (I marciumi radicali nelle foreste campane: tentativi di lotta biologica ed integrata). Atti Convegno Pom A-24 "Innovazioni nella difesa dalle malattie di piante agrarie e forestali con mezzi di lotta biologica ed integrata", Cisternino (Br), 21-23 Novembre, 157-170. 
Pirazzi R., Bragaloni M., Anselmi N., 1996. Mycorrhization of root systems in beech plants characterized by different health status. (Micorrizazione degli apparati radicali in piante di faggio caratterizzate da differente stato sanitario). Micologia Italiana, XXV, 3, 61-68

Raabe, R.D. 1979. Resistance or susceptibility of certain plants to Armillaria Root Rot. University of California, Berkeley, Leaflet 2591, 18pp.

Sciré M., D’Amico L., Gaglioppa P., Puddu G., Tizzani L., Motta E., 2011. First record of Armillaria mellea on Ailanthus altissima in Italy. (Prima segnalazione di Armillaria mellea su Ailanthus altissima in Italia). Micol. Ital., 3, 17-22

Sicoli, G., Annese V., Gioia T. de, Luisi N., 2002. Armillaria pathogenicity tests on oaks in southern Italy, Journal of Plant Pathology, 84 (2), 107-111

Shaw III C.G. and Kile G A., 1991. Armillaria root disease. Agriculture Handbook $\mathrm{N}^{\circ}$ 691, Forest Service United States Department of Agriculture, Washington, DC, 233pp.

Tirrò, A., Rapisarda, A.M. 1989. Identification of species of the genus Armillaria in some Sicilian areas. (Identificazione di specie del genere Armillaria in alcuni comprensori siciliani). Micol. Ital., 1, 15-25.

Torta L., Burruano S., Anselmi N., 2016. Health status and mycorrhization in forest tree species: case studies in Italy. (Stato sanitario e micorrizazione in specie arboree forestali: casi studio in Italia). "XXII Convegno Nazionale di Micologia" dell'Associazione Micologica Italiana (UMI), L'Aquila, 1213 settembre, 1p. (summary)

Vannini A. and Magro P., 1987. Root rot by Armillaria mellea on Actinidia chinensis in the north of Latium. Proceedings of the "7th Congress of the Mediterranean Phytopathological Union." Granada (Spain) 20-26 September 1987, p. 191 (summary). 